\title{
Tax Revenue, Total Expense, Gross Domestic Production and Budget Deficit: A Study in Sri Lanka
}

\author{
Vickneswaran Anojan ${ }^{1}$ \\ ${ }^{1}$ Lecturer (Probationary), Department of Accounting, University of Jaffna, Sri Lanka \\ Correspondence: Vickneswaran Anojan, Lecturer (Probationary), Department of Accounting, University of Jaffna, \\ Sri Lanka
}

Received: July 10, 2018

Accepted: August 14, 2018

Online Published: August 24, 2018

doi:10.5430/afr.v7n4p17

URL: https://doi.org/10.5430/afr.v7n4p17

\begin{abstract}
The main aim of this study is to find out relationship among tax revenue, total expense, gross domestic production and budget deficit of Sri Lanka from 1990 to 2015. Budget deficit is a vital problem in Sri Lanka. This research mainly considers three independent variables such as tax revenue, total expense and gross domestic production and budget deficit is dependent variable of this research. Data of this study collected from annual report, ministry of finance and central bank reports of Sri Lanka. Descriptive and inferential statistics were performed with the help of SPSS to analyze research data, answer research questions, reach research objectives and test hypothesis in this study. Correlation analysis confirmed that there are positive significant relationship between direct tax revenue and gross domestic production (98.4\%), direct tax revenue and budget deficit (98.6\%), indirect tax revenue and gross domestic production $(99.2 \%)$, indirect tax revenue and budget deficit $(98.5 \%)$, capital expense and gross domestic production (99.3\%), capital expense and budget deficit (98.5\%), recurrent expense and gross domestic production (98.7\%), recurrent expense and budget deficit (99.3\%), gross domestic production and budget deficit (97.2\%) of Sri Lanka from 1990 to 2015. Regression analysis confirmed that $98.9 \%$ of gross domestic production depends on capital expense, recurrent expense, direct tax revenue and indirect tax revenue of the Sri Lanka. Capital expense has significant impact on the gross domestic production of the country $(\mathrm{P}=0.024)$. $99.4 \%$ of budget deficit depends on capital expense, recurrent expense, direct tax and indirect tax of Sri Lanka. Further it can be stated that indirect tax revenue and recurrent expense have significant impact on the budget deficit of Sri Lanka $(\mathrm{P}<0.05)$. This study concludes that there is possibility to change budget deficit and gross domestic production through capital expense, recurrent expense, direct tax revenue and indirect tax revenue in Sri Lanka.
\end{abstract}

Keywords: tax revenue, recurrent expense, capital expense, gross domestic production, budget deficit and Sri Lanka

\section{Introduction}

Economy is one of the key elements of sustainable development. Tax revenue, total expense, gross domestic production and budget deficit is the key indicators of economy and budget deficit is a major economic problem in Sri Lanka. Especially continuous budget deficit is very serious problem for more than 50 years in Sri Lanka. Budget deficit is continuing every year in Sri Lanka. Lymer and Oats (2009) stated that taxation is a key economic tool for well managing country's income; taxation has played a significant role in developed countries. Fiscal policy is very important for every country. It should be amended according to the economic conditions, sustainable development and expectations of the country. Generally numbers of tax policy changes are often occurring in every budget to increase tax revenue and try to reduce budget deficit in every country. Tax policy changes mean that abolish some existing tax policy in the tax system. These changes may withdraw old tax from taxation; add new tax to taxation, increase tax rates, decrease tax rates and etc. Tax policy changes will differ from country to country according to their economic policy.

\section{Literature Review}

\subsection{Theoretical Review}

\subsubsection{Tax Revenue (TR)}

Government total revenue could be divided into tax revenue and non-tax revenue. Tax revenue is one of the major revenue of government revenue. According to central bank report (2016), more than $86 \%$ of government revenue comes from tax revenue in Sri Lanka. Direct tax revenue and indirect tax revenue are major two revenues under tax 
revenue. According to central bank report (2016), it can be seen that more than $80 \%$ tax revenue of Sri Lanka has been generated by indirect taxes. According to Lymer and Oats (2009), they defined tax is a compulsory levy which is imposed on income, business, expenditure or capital assets by government and other tax authority. Here income tax payers does not receive any specific return as directly however they are receiving some advantages as indirectly such as free health, education, national security, infrastructure facilities, livelihood assistances and etc. Here charges, tolls and other levies do not consider as tax payments. Those are paid to obtain a specific service from the government. Tax collection is much important for every country to their effective and efficient economic operation. Singh (1999), Shanmugam (2003) \& Lymer and Oats (2009) pointed that generate revenues for public expenditure is one of the major objective of tax collection in every country.

\subsubsection{Total Expense (TE)}

Government total expense can be divided into two major parts such as total recurrent expense and total capital expense. Sri Lankan government total current expense's includes the following major expenses such as salaries and wages, other goods and services, interest payments and current transfers and subsidies. Capital expense includes acquisition of real assets and capital transfers. According to central bank report (2016), it can be seen that government spending has increased to 1,015,106.70 LKR Million from 985,815 LKR Million in 2016. An average expense of Sri Lanka is 151,449.44 LKR Million from 1950 until 2016. Sri Lanka reached 1,015,106.70 LKR Million in 2016 which is high level government expense in Sri Lanka and Sri Lanka had 440 LKR Million expense in 1950 which is very low level government expense in Sri Lankan history.

\subsubsection{Gross Domestic Production (GDP)}

Gross Domestic Production (GDP) Gross domestic production is the total economic production of the country which consist three major sector such as agriculture, industrial and service sector. Gross domestic production, direct tax revenue, indirect tax revenue and government expense have interrelation among them. Economic growth of the country is calculated based on the present and past year gross domestic production of the country. According to annual report of central bank (2016), Sri Lankan economy has grown by $4.4 \%$ in real terms even though it had several international and national economic challenges. There are number of factors are impact on the gross domestic production of the country. Unfavorable weather conditions of Sri Lanka adversely impacted economic activities especially it was seriously affected agriculture sector of Sri Lanka in last year. Service sector of Sri Lanka has increased by $4.2 \%$ of GDP in 2016. Expansion in financial service, insurance, telecommunications, transportation and whole sale and retail trade is the major reason for this greatest achievement in service sector of Sri Lanka. Industry sector also has grown by $6.7 \%$ in Sri Lanka. Industry sector has contributed $26.8 \%$ to the gross domestic production of Sri Lanka in 2016.

\subsubsection{Budget Deficit (BD)}

Generally government budget includes revenue, expense, budget surplus/ deficit and financing/ investment for one year period. Tax revenue is major source of revenue as well as recurrent expenses and capital expenses are major expenses. Budget deficit means that government total revenue less than its total expense. Budget deficit is a major problem for every country in the current world. Sri Lanka has budget deficit in every year although it is differing from year to year but the current budget deficit is not as good level. There are number of reason for the budget deficit of the country but it can be confirmed that government revenue and expense. Especially Sri Lanka is providing many free services as well as with minimum payment such as free education, samurdhy, electricity, postal, transport, free health, free try foods, etc... above reasons and inefficiency in tax collection, tax evasion, inefficient tax policy, past civil war and resettlement could be seen as reasons for facing budget deficit in Sri Lanka. According to the central bank report (2016), it can be seen that budget deficit of Sri Lanka was 5.40 percentage of gross domestic production in 2016.

\subsection{Empirical Review}

According to best of researcher knowledge and availability of information, researcher was unable to find any research on this particular research topic. The following empirical evidence found by the researcher which is more related with this study. Muriithi (2013) pointed that all taxes have disincentive impact such as taxes adversely impact of investment on human, physical capital and innovation or creativity of the country. This research main objective was to reveal association between economic growth of Kenya and government revenue of Kenya. Results of this study concluded that adverse association between import duty and economic growth of the country which means that if any increase in import duty that reduce economic growth of Kenya and vice versa. This study results reveal that any increase in excise duty which reduce slowly rate of economic growth of the country. Major findings of this study 
were existing income tax policy leads to increase in the tax revenue of the country in every year and income tax had direct association with economic growth. That means if any increase in the income tax that will directly associate with economic growth of the country. Further this study found that there is positive impact of increase in value added tax on the rate of economic growth of Kenya. Researcher concluded that economic growth of Kenya has been increased in over the past years.

According to Chaudhry and Munir (2010), tax collection was one of the significant economic issues for the economic development of the country. Results of this study reveal that determinants of tax efforts significantly depend on openness, broad money, external debt, foreign aid and political stability. Agriculture, manufacturing and service sector share turn out to be insignificant. This study concluded that openness, money supply and political stability are boosting variables to increase level of taxation. Gacanja (2012) did a study to find association between economic growth and tax revenues. Based on the results of this study, researcher stated that there was positive association between economic growth and tax revenue of Kenya. This study covered income tax, import duties, excise duties and value added tax as tax variables. Tax variables were positively impact on gross domestic production of the country. Value added tax had high impact on GDP and import duties had low level of impact on GDP. According to the results of this study, researcher suggested that government should desist from concentrating on increasing tax revenues by increasing tax levels but instead employ a tax structure that enhances the tax base thus improving economic growth rate.

James (2003) found that there was a positive and statistically significant relationship between the share of government expenditure in gross domestic product and the share of net disbursement of overseas development assistance. Further findings reveal that foreign aid leads to tax relief and there was a strong indication for usage of foreign aid for recurrent expenditure of the country. Worlu and Emeka (2012) examined about impact of tax revenue on the economic growth of Nigeria from 1980 to 2007. They found that tax revenue stimulates economic growth through infrastructural development. Further major findings of this study highlighted tax revenue impacts on economic growth in Nigeria. Eric and Jonathan (1996) noted tax reforms are sometimes touted as having strong macroeconomic growth effects. They used three approaches to find the impact of a major tax reform 5 percentage point cut in marginal tax rates on long term growth rates in this study. The first approach was to examine the historical record of the United States' economy to evaluate whether tax cuts have been associated with economic growth. The second was to consider the evidence on taxation and growth for a large sample of countries. Final approach was micro level studies of labor supply, investment demand, and productivity growth. Results of this study suggested modest effects, on the order of 0.2 to 0.3 percentage point differences in growth rates in response to a major tax reform.

Margareta and Asa (2012) pointed that there are several ways to collect and increase tax revenue of the country. Here every ways may have different impact on economic growth of the country. They found that both taxation of corporate and personal income negatively influence economic growth. The correlation between corporate income taxation and economic growth is more robust. Mahdavi (2008) found that the effect of rises in total tax revenue will reduce the growth in developing countries. Due to by the fiscal crisis and tax policy changes in the past several decades, several developing countries had to revive its economy by changing the level of taxes through tax policy changes. Hinrisch (1966) and Musgrave (1969) studied the relationship between the ratios of tax revenue to gross domestic production and they found that it was relatively low in the developing countries. African countries by Leuthold (1991) did a study to find ratios of tax revenue to gross domestic production. This study covered 8 years from 1973 to 1981. They used the Ordinary Least Squares (OLS) estimation method. According to the results of this study it can be seen that share of agriculture impact the level of taxation and robust the relationship of total tax revenue into direct taxes as well indirect taxes.

A study by Mahdavi (2008) stated effect of income, profit and capital gain tax due to change in inflation rate and investment plans. Based on this study it can be found that when the inflation rates increase, the household will protect their assets by substituting it with the assets that less domestic tax such as Jewelleries. According to the study of Glomm and Ravikumar (1998) mentioned that when government reduces capital income taxes, that will reduce the spending on education and the long run growth of the countries. Capital income taxes had positive correlation with the economic growth of the countries. Besides, Gober and Burns (1997) did a study to find association between tax structure and economic indicators for the OECD countries. According to the findings of this study it can be seen that total tax revenue had negative association with saving and investment of OECD countries. Further it was found that personal income tax, corporate income tax, sales tax and other taxes were significantly impact on economic growth and also there were positive relationship between personal income tax, corporate income tax, sales tax and other taxes and economic growth of OECD countries. Friedman (1978) stated that an increase in the amount of revenues 
only provides governments with additional resources. Researcher suggested that expenditure must reduce to achieve budget deficit reductions of the country.

\section{Methodology}

\subsection{Conceptual Framework}

The following conceptual model clearly reveals relationship among tax revenue, total expense, gross domestic production and budget deficit. Here tax revenue includes direct and indirect tax revenue as well as total expense includes recurrent and capital expense.

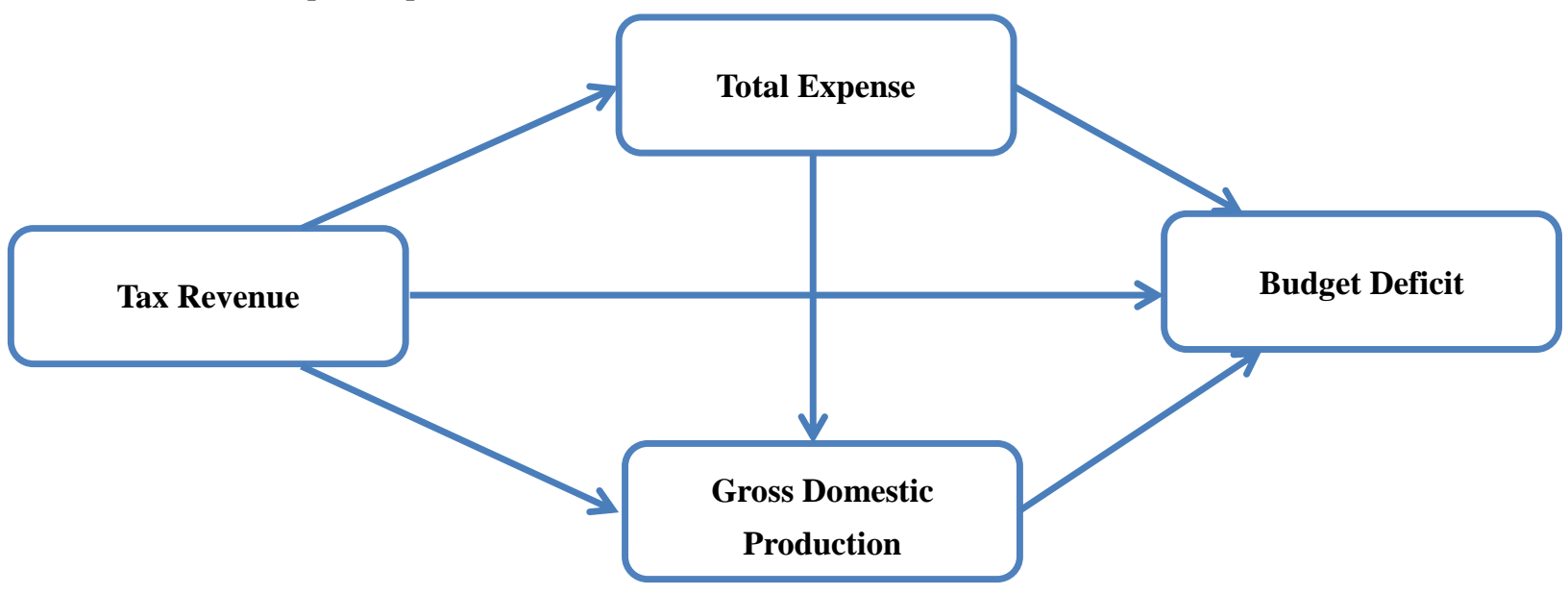

Figure 1. Conceptual Model

\section{Source: Constructed based on literature review}

\subsection{Operationalization of the Variables}

The following table very clearly shows about the concept, variables, indicators and measures of this study.

Table 1. Operationalization of variables used in the study

\begin{tabular}{|c|c|c|c|}
\hline Concept & Variables & Indicators & Measures \\
\hline Tax Revenue & $\begin{array}{l}\text { Direct Tax Revenue } \\
\text { Indirect Tax Revenue }\end{array}$ & $\begin{array}{l}\text { Direct and Indirect Tax } \\
\text { Revenue of the } \\
\text { Country from } 1990 \text { to } \\
2015\end{array}$ & 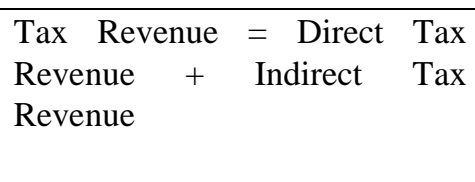 \\
\hline Total Expense & $\begin{array}{l}\text { Recurrent Expense } \\
\text { Capital Expense }\end{array}$ & $\begin{array}{l}\text { Recurrent and Capital } \\
\text { Expense of the } \\
\text { Country from } 1990 \text { to } \\
2015\end{array}$ & $\begin{array}{l}\text { Total Expense }=\text { Recurrent } \\
\text { Expense }+ \text { Capital Expense }\end{array}$ \\
\hline $\begin{array}{l}\text { Gross } \quad \text { Domestic } \\
\text { Production (GDP) }\end{array}$ & $\begin{array}{l}\text { Amount of Gross } \\
\text { Domestic Production }\end{array}$ & $\begin{array}{l}\text { Gross Domestic } \\
\text { Production of the } \\
\text { Country from } 1990 \text { to } \\
2015\end{array}$ & $\begin{array}{l}\text { Present year amount of Gross } \\
\text { Domestic Production at Current } \\
\text { Price }\end{array}$ \\
\hline Budget Deficit (BD) & Amount of Budget Deficit & $\begin{array}{l}\text { Fiscal Deficit of the } \\
\text { Country from } 1990 \text { to } \\
2015\end{array}$ & $\begin{array}{l}\text { Total Government Revenue - } \\
\text { Total Government Expenditure }\end{array}$ \\
\hline
\end{tabular}

\subsection{Sample Design and Data Collection}

\subsubsection{Population and Study Sample}

The secondary data used in this study which were collected from the central bank reports and department of Inland Revenue's reports and publications. This study considered whole of the Sri Lanka not only for one specific area. This study covered the period from 1990 to 2015 which covered 26 years in this study. 


\subsubsection{Sources of Data}

Secondary data used in this study those secondary data which were collected from central bank reports of Sri Lanka from 1990 to 2015, publications of Inland Revenue, text book, journals, magazines and local newspapers. Statistical analyses of this study have been done with the help of the published annual reports of central bank from 1990 to 2015. Numbers of previous study and published journal article have been used in this study to acquire the depth theoretical and empirical sound knowledge on this research area.

\subsection{Hypotheses}

The following hypotheses were developed and tested in this study based on the research questions and objectives of this study.

$\mathbf{H}_{\mathbf{1}}$ : There is significant relationship among direct tax revenue, indirect tax revenue, recurrent expense, capital expense, gross domestic production and budget deficit of Sri Lanka.

$\mathrm{H}_{2}$ : Direct tax revenue, indirect tax revenue, recurrent expense and capital expense are significantly impact on gross domestic production of Sri Lanka.

$\mathbf{H}_{2 \mathbf{a}}$ : Direct tax revenue is significantly impact on gross domestic production of Sri Lanka.

$\mathbf{H}_{2 b}$ : Indirect tax revenue is significantly impact on gross domestic production of Sri Lanka.

$\mathbf{H}_{2 \mathrm{c}}$ : Recurrent expense has significant impact on gross domestic production of Sri Lanka.

$\mathbf{H}_{2 \mathrm{~d}}$ : Capital expense has significant impact on gross domestic production of Sri Lanka.

$\mathrm{H}_{3}$ : Direct tax revenue, indirect tax revenue, recurrent expense and capital expense are significantly impact on budget deficit of Sri Lanka.

$\mathbf{H}_{3 \mathbf{a}}$ : Direct tax revenue is significantly impact on budget deficit of Sri Lanka.

$\mathbf{H}_{3 \mathbf{b}}$ : Indirect tax revenue is significantly impact on budget deficit of Sri Lanka.

$\mathbf{H}_{3 \mathbf{c}}$ : Recurrent expense has significant impact on budget deficit of Sri Lanka.

$\mathbf{H}_{3 \mathbf{d}}$ : Capital expense has significant impact on budget deficit of Sri Lanka.

\subsection{Research Model}

The following simple statistical models formulated and tested in this study. To identify the impact of direct tax revenue, indirect tax revenue, recurrent expense and capital expense on gross domestic production of Sri Lanka, a regression model (1) estimated as below.

$$
Y=\beta o+\beta_{1} X_{1}+\beta_{2} X_{2}+\beta_{3} X_{3}+\beta_{4} X_{4}--------\varepsilon_{i}
$$

To identify the impact of direct tax revenue, indirect tax revenue, recurrent expense and capital expense on budget deficit of Sri Lanka, a regression model (2) estimated as below.

$$
Y_{1}=\beta o+\beta_{1} X_{1}+\beta_{2} X_{2}+\beta_{3} X_{3}+\beta_{4} X_{4}+--------\varepsilon_{i}
$$

\section{Where:}

Y

$\mathbf{Y}_{1}$

$\boldsymbol{\beta}_{\mathbf{o}}$

$\beta_{1}$

$\boldsymbol{\beta}_{2}$

$\beta_{3}$

$\boldsymbol{\beta}_{4}$

$\mathrm{X}_{1}$

$\mathbf{X}_{2}$

$\mathbf{X}_{3}$

$\mathbf{X}_{4}$

And $\quad \varepsilon_{i}$
$=$ Gross Domestic Production

$=$ Budget Deficit

$=$ Constant

$=\quad$ Direct Tax Revenue Changes Slope

$=\quad$ Indirect Tax Revenue Changes Slope

$=\quad$ Recurrent Expense Changes Slope

$=\quad$ Capital Expense Changes Slope

$=$ Direct Tax Revenue Changes

$=$ Indirect Tax Revenue Changes

$=$ Recurrent Expense Changes

$=$ Capital Expense Changes

$=$ Random Error 


\subsection{Data Analysis Strategies}

This study involves with statistical analysis and secondary data. Researcher used SPSS to analyze the data of this study which is very popular software for secondary data as well as quantitative analysis. The following analysis were performed in this study such as,

Descriptive analysis used to reveals the mean value of direct tax revenue, indirect tax revenue, current expense, capital expense, gross domestic production and budget deficit of Sri Lanka from 1990 to 2015. The ultimate purpose of descriptive analysis is to reveals the average value of direct tax revenue, indirect tax revenue, current expense, capital expense, gross domestic production in million rupees. Correlation Analysis used to find out the relationship among direct tax revenue, indirect tax revenue, current expense, capital expense, gross domestic production and budget deficit of Sri Lanka from 1990 to 2015. Also correlation analysis is important to find out significant and positive/ negative relationship. Correlation analysis used to test the hypothesis one of this study.

Regression Analysis used to find out the impact of direct tax revenue, indirect tax revenue, recurrent expense and capital expense on gross domestic production of Sri Lanka from 1990 to 2015. Further regression analysis used to find out the impact of direct tax revenue, indirect tax revenue, recurrent expense and capital expense on budget deficit of Sri Lanka from 1990 to 2015. Regression analysis used to test the hypothesis two and three of this study. It is very important to develop the statistical regression model according to the independent variables impact on the dependent variables of this study.

\section{Analysis}

4.1 Graphical Analysis

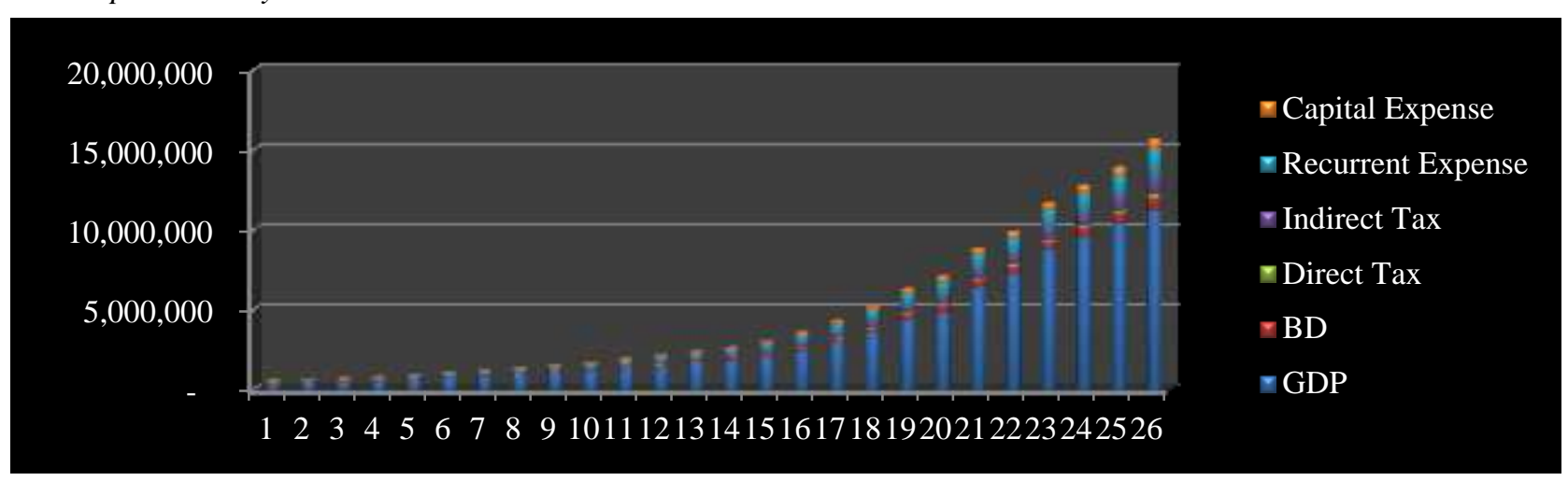

Figure 2. Direct tax revenue, indirect tax revenue, current expense, capital expense, gross domestic production and budget deficit of Sri Lanka from 1990 to 2015.

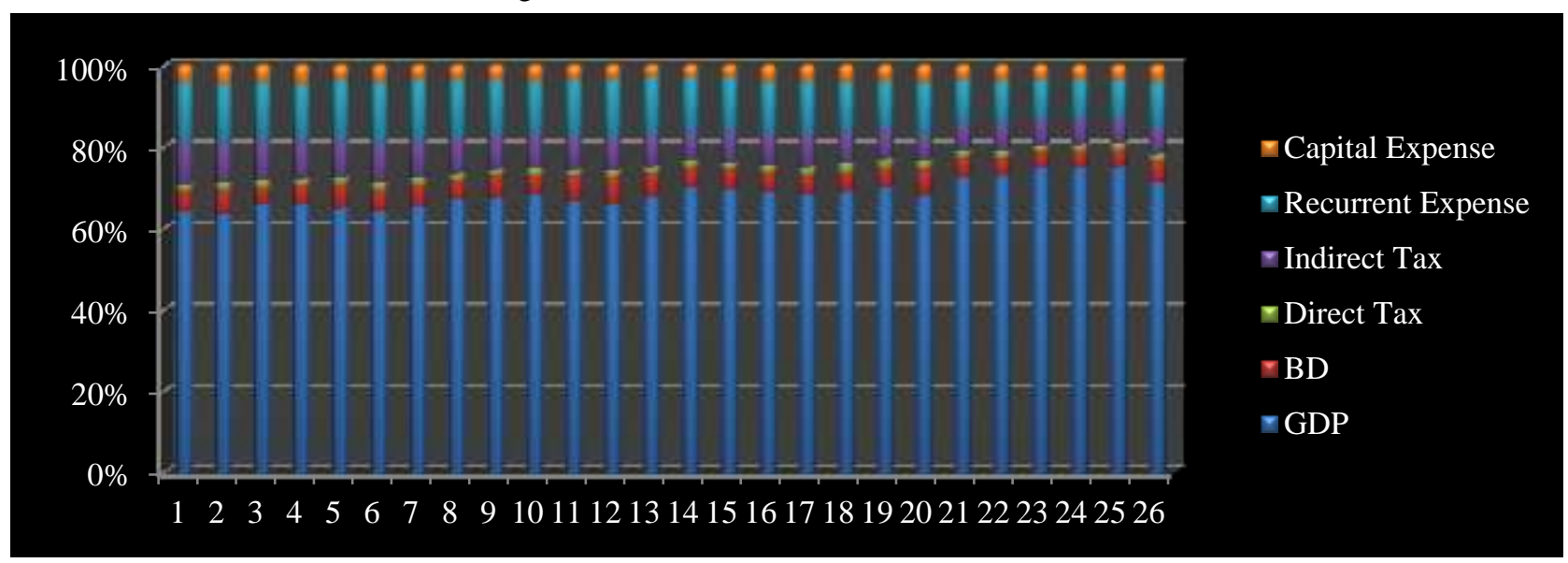

Figure 3. Direct tax revenue, indirect tax revenue, current expense, capital expense, gross domestic production and budget deficit of Sri Lanka from 1990 to 2015.

Above figures 2 and 3 shows the trends of direct tax revenue, indirect tax revenue, current expense, capital expense, gross domestic production and budget deficit of Sri Lanka from 1990 to 2015. From the figure 3 it can be seen that direct tax revenue percentage was same as in every year, budget deficit was very high level percentage in 2001 and it 
was very low level in 2013. It shows that Sri Lanka had very high level indirect tax revenue in 1990 and very low level indirect tax revenue in 2013 and 2014. Recurrent expense was very high level in 1990 and it was very low level percentage in 2013 and 2014. Capital expense was very high level in 2005 and 2006. Capital expense was very low level in 2002 and 2004. Gross domestic production was increased than 70 percentage after 2010 to 2014 however gross domestic production was reduced in 2015. Gross domestic production was very high level percentage in 2014 and very low level percentage in 1991.

4.2 Descriptive Analysis

Table 2. Descriptive Analysis

\begin{tabular}{lllllll}
\hline & Range & Minimum & Maximum & Mean & Std. Deviation & Variance \\
\hline GDP & $1 . \mathrm{E} 7$ & 321,784 & $10,000,000$ & $3,330,000$ & 3442854.995 & $1.185 \mathrm{E} 13$ \\
BD & 804,350 & 25,152 & 829,502 & 229,000 & 216146.451 & $4.672 \mathrm{E} 10$ \\
DT & $2.55 \mathrm{E} 5$ & 7,335 & 263,000 & 76,216 & 74337.64799 & $5.526 \mathrm{E} 9$ \\
IDT & $1.04 \mathrm{E} 6$ & 53,871 & $1,090,000$ & 331,050 & $2.93721 \mathrm{E} 5$ & $8.627 \mathrm{E} 10$ \\
RCE & $1.63 \mathrm{E} 6$ & 71,771 & $1,700,000$ & 521,160 & $4.54603 \mathrm{E} 5$ & $2.067 \mathrm{E} 11$ \\
CE & $5.69 \mathrm{E} 5$ & 19,529 & 588,000 & 165,800 & $1.66412 \mathrm{E} 5$ & $2.769 \mathrm{E} 10$ \\
\hline
\end{tabular}

Source: Secondary Data

Table 2 descriptive analyses clearly show that range, minimum, maximum, mean, standard deviation and variance in billion rupees. Mean value of gross domestic production, budget deficit, direct tax revenue, indirect tax revenue, recurrent expense and capital expense were LKR 3,330,000, 229,000, 76,216, 331,050, 521,160 and 165,800 billion respectively. Here direct tax revenue is very low level and capital expense also is very low level in Sri Lanka. Mean value of recurrent expense is very high level which is more than the total of direct and indirect tax revenue of Sri Lanka. It can be pointed that tax revenue is not enough even to meet the recurrent expense of Sri Lanka. Sri Lanka has been spent 3.15 times of capital expense for recurrent expense. Direct tax revenue is not enough to meet the capital expense of Sri Lanka. Government of Sri Lanka should try to increase the direct tax and non-tax revenue to meet at least the capital expense or Sri Lanka should try to manage the capital expense within the total of direct tax and non-tax revenue of the country. Also government should try to increase the gross domestic production. Sri Lanka can increase indirect tax revenue to meet the recurrent expense of the country. Sri Lanka ought to try to control the recurrent expense within indirect tax revenue of the country. 


\subsection{Correlation Analysis}

Table 3. Correlation Analysis

\begin{tabular}{|c|c|c|c|c|c|c|c|}
\hline & & GDP & $\mathrm{BD}$ & DT & IDT & $\mathrm{RCE}$ & $\mathrm{CE}$ \\
\hline \multirow[t]{3}{*}{ GDP } & Pearson Correlation & 1 & $.972^{* *}$ & $.984^{* *}$ & $.992^{* *}$ & $.987^{* *}$ & $.993^{* *}$ \\
\hline & Sig. (2-tailed) & & .000 & .000 & .000 & .000 & .000 \\
\hline & $\mathrm{N}$ & 26 & 26 & 26 & 26 & 26 & 26 \\
\hline \multirow[t]{3}{*}{$\mathrm{BD}$} & Pearson Correlation & $.972^{* *}$ & 1 & $.986^{* *}$ & $.985^{* *}$ & $.993^{* *}$ & $.985^{* *}$ \\
\hline & Sig. (2-tailed) & .000 & & .000 & .000 & .000 & .000 \\
\hline & $\mathrm{N}$ & 26 & 26 & 26 & 26 & 26 & 26 \\
\hline \multirow[t]{3}{*}{ DT } & Pearson Correlation & $.984^{* *}$ & $.986^{* *}$ & 1 & $.993^{* *}$ & $.994^{* *}$ & $.995^{* *}$ \\
\hline & Sig. (2-tailed) & .000 & .000 & & .000 & .000 & .000 \\
\hline & $\mathrm{N}$ & 26 & 26 & 26 & 26 & 26 & 26 \\
\hline \multirow[t]{3}{*}{ IDT } & Pearson Correlation & $.992^{* *}$ & $.985^{* *}$ & $.993^{* *}$ & 1 & $.997^{* *}$ & $.997^{* *}$ \\
\hline & Sig. (2-tailed) & .000 & .000 & .000 & & .000 & .000 \\
\hline & $\mathrm{N}$ & 26 & 26 & 26 & 26 & 26 & 26 \\
\hline \multirow[t]{3}{*}{$\mathrm{RCE}$} & Pearson Correlation & $.987^{* *}$ & $.993^{* *}$ & $.994^{* *}$ & $.997^{* *}$ & 1 & $.994^{* *}$ \\
\hline & Sig. (2-tailed) & .000 & .000 & .000 & .000 & & .000 \\
\hline & $\mathrm{N}$ & 26 & 26 & 26 & 26 & 26 & 26 \\
\hline \multirow[t]{3}{*}{$\mathrm{CE}$} & Pearson Correlation & $.993^{* *}$ & $.985^{* *}$ & $.995^{* *}$ & $.997^{* *}$ & $.994^{* *}$ & 1 \\
\hline & Sig. (2-tailed) & .000 & .000 & .000 & .000 & .000 & \\
\hline & $\mathrm{N}$ & 26 & 26 & 26 & 26 & 26 & 26 \\
\hline
\end{tabular}

Source: Secondary Data

Table 3 shows correlation among direct tax revenue, indirect tax revenue, capital expense, recurrent expense, gross domestic production and budget deficit of Sri Lanka from 1990 to 2015. According to the above correlation analysis it can be seen that there is positive significant relationship between direct tax and budget deficit. There is positive relationship between indirect tax revenue and budget deficit. According to the above table, there is positive significant relationship between capital expense and budget deficit. There is positive significant relationship between recurrent expense and budget deficit. Also direct tax, indirect tax, capital expense and recurrent expense have positive significant relationship with gross domestic production of Sri Lanka $(\mathrm{P}<0.05)$.

\subsection{Regression Analysis}

Table 4. Model Summary

\begin{tabular}{ccccc}
\hline Model & $\mathrm{R}$ & R Square & Adjusted R Square & Std. Error of the Estimate \\
\hline 1 & $.994^{\mathrm{a}}$ & .989 & .986 & 401343.363 \\
\hline
\end{tabular}

a. Predictors: (Constant), Capital expense, Recurrent expense, Direct tax, Indirect tax 
Table 5. ANOVA table in the Regression Analysis

\begin{tabular}{lllllll}
\hline Model & & Sum of Squares & $\mathrm{df}$ & Mean Square & $\mathrm{F}$ & Sig. \\
\hline 1 & Regression & $2.929 \mathrm{E} 14$ & 4 & $7.324 \mathrm{E} 13$ & 454.673 & $.000^{\mathrm{a}}$ \\
& Residual & $3.383 \mathrm{E} 12$ & 21 & $1.611 \mathrm{E} 11$ & & \\
& Total & $2.963 \mathrm{E} 14$ & 25 & & & \\
\hline
\end{tabular}

a. Predictors: (Constant), Capital expense, Recurrent expense, Direct tax, Indirect tax

b. Dependent Variable: Gross domestic production

Table 6. Coefficients table in the Regression Analysis

\begin{tabular}{llccccc}
\hline Model & & $\begin{array}{c}\text { Unstandardized } \\
\text { Coefficients B }\end{array}$ & Std. Error & $\begin{array}{c}\text { Standardized } \\
\text { Coefficients Beta }\end{array}$ & $\mathrm{T}$ & Sig. \\
\hline 1 & (Constant) & -246211.336 & 179819.663 & & -1.369 & .185 \\
& DT & -20.017 & 13.269 & -.432 & -1.508 & .146 \\
& IDT & 6.226 & 5.476 & .531 & 1.137 & .268 \\
RCE & -.315 & 2.855 & -.042 & -.110 & .913 \\
& CE & 19.336 & 7.951 & .935 & 2.432 & .024 \\
\hline
\end{tabular}

a. Dependent Variable: Gross domestic production

Sources: Secondary Data

According to the table 4 , it can be seen that model summary $R$ square $\left(R^{2}\right) 0.989$. It means that there is $98.9 \%$ impact of the independent variables (capital expense, recurrent expense, direct tax and indirect tax) on the dependent variable (gross domestic production). Above table 5 ANOVA table in the regression analysis which is significant here $\mathrm{P}$ value is 0.000 . It is below than the level 0.01 or $1 \%$. Therefore, researcher can conclude that $1 \%$ of the impact is in the significant level. From the table 6 coefficients table in the regression analysis, it can be seen that capital expense has significant impact on the gross domestic production of the country. Therefore the government should try to increase the capital expenses in order to increase the gross domestic production of the country. Finally, in terms of the regression analysis, researcher can state that the there is significant impact of capital expense, recurrent expense, direct tax, indirect tax on the gross domestic production of the country.

Table 7. Model Summary

\begin{tabular}{lrrrrr}
\hline Model & $\mathrm{R}$ & \multicolumn{2}{c}{ R Square } & Adjusted R Square & \multicolumn{2}{c}{ Std. Error of the Estimate } \\
\hline 1 & $.997^{\mathrm{a}}$ & & .994 & .992 & 18794.924 \\
\hline
\end{tabular}

a. Predictors: (Constant), Capital expense, Recurrent expense, Direct tax, Indirect tax

Table 8. ANOVA table in the Regression Analysis

\begin{tabular}{llccccc}
\hline Model & & Sum of Squares & df & Mean Square & F & Sig. \\
\hline 1 & Regression & $1.161 \mathrm{E} 12$ & 4 & $2.901 \mathrm{E} 11$ & 821.349 & $.000^{\mathrm{a}}$ \\
& Residual & $7.418 \mathrm{E} 9$ & 21 & $3.532 \mathrm{E} 8$ & & \\
& Total & $1.168 \mathrm{E} 12$ & 25 & & & \\
\hline
\end{tabular}

a. Predictors: (Constant), Capital expense, Recurrent expense, Direct tax, Indirect tax

b. Dependent Variable: Budget deficit 
Table 9. Coefficients table in the Regression Analysis

\begin{tabular}{llccccc}
\hline Model & & $\begin{array}{c}\text { Unstandardized } \\
\text { Coefficients B }\end{array}$ & Std. Error & $\begin{array}{c}\text { Standardized } \\
\text { Coefficients Beta }\end{array}$ & $\mathrm{t}$ & Sig. \\
\hline 1 & (Constant) & -9841.829 & 8420.961 & & -1.169 & .256 \\
& DT & -1.289 & .621 & -.443 & -2.074 & .051 \\
& IDT & -1.157 & .256 & -1.572 & -4.512 & .000 \\
& RCE & 1.060 & .134 & 2.229 & 7.925 & .000 \\
& CE & 1.010 & .372 & .778 & 2.714 & .013 \\
\hline
\end{tabular}

a. Dependent Variable: Budget deficit

Sources: Secondary Data

According to the table 7, it can be seen that model summary $R$ square $\left(R^{2}\right) 0.994$. It means that there is $99.4 \%$ impact of the independent variables (capital expense, recurrent expense, direct tax and indirect tax) on the dependent variable (budget deficit). Above table 8 ANOVA table in the regression analysis which is significant here $\mathrm{P}$ value is 0.000 . It is below than the level 0.01 or $1 \%$. Therefore, researcher can conclude that $1 \%$ of the impact is in the significant level. From the table 9 coefficients table in the regression analysis, it can be seen that indirect tax revenue has significant impact on the budget deficit and also recurrent expense has significant impact on the budget deficit of the country. Therefore it can be found that indirect tax revenue and recurrent expense are major sources to improve the budget deficit of the country so the government should try to use greatest economic policy to improve the indirect tax revenue and reduce or maintain the recurrent expense of the country. There is two major variables impact on the budget such as revenue and expense. Any country cannot focus only revenue or expense. Both should be considered here revenue depends on the expenses as well expense depends on the revenue. Sri Lanka does not have adequate revenue for the country expense so there are other ways to finance to the expense. Especially Sri Lanka has two major practices for the over expense rather than the total revenue of the country such as grant/ loan. Government is doing this practice over a several years in Sri Lanka here it should be considered that this practice also one of the reason to have high and increasing budget deficit in every year because when the government has to settle the loan or repay the loan installment, the government has to pay interest additionally. Generally Sri Lanka has budget deficit in every year so the government does not have any option rather than loan or grant to finance budget deficit. This practice will bring huge liability for the future generation of the country at the same time it will seriously impact on the sustainable development of the country. Purchasing and public officers' remuneration and pension are the major expenses of the recurrent expense of the country so the public staffs of the country has vital responsibility on reduce the budget deficit of the country. Finally, in terms of the regression analysis, researcher can state that the there is significant impact of current expense, recurrent expense, direct tax, indirect tax on the budget deficit of the country, the government should try to develop the greatest fiscal and economic policy to improve/ reduce budget deficit of the country in near future. 


\subsection{Hypotheses Testing}

Table 10. Hypotheses Testing

\begin{tabular}{|c|c|c|c|c|}
\hline NO & Hypotheses & Tools & P-Value & Results \\
\hline $\mathbf{H}_{1}$ & $\begin{array}{l}\text { There is significant relationship among tax revenue, total } \\
\text { expense, gross domestic production and budget deficit of Sri Lanka. }\end{array}$ & Correlation & .000 & Accepted \\
\hline $\mathbf{H}_{2}$ & $\begin{array}{l}\text { Direct tax, indirect tax revenue, recurrent and capital expense are } \\
\text { significantly impact on gross domestic production of Sri Lanka. }\end{array}$ & Regression & .000 & Accepted \\
\hline $\mathbf{H}_{2 \mathrm{a}}$ & $\begin{array}{l}\text { Direct tax revenue is significantly impact on gross domestic } \\
\text { production of Sri Lanka. }\end{array}$ & Regression & .146 & Rejected \\
\hline $\mathbf{H}_{2 b}$ & $\begin{array}{l}\text { Indirect tax revenue is significantly impact on gross domestic } \\
\text { production of Sri Lanka. }\end{array}$ & Regression & .268 & Rejected \\
\hline $\mathbf{H}_{2 \mathrm{c}}$ & $\begin{array}{l}\text { Recurrent expense has significant impact on gross domestic } \\
\text { production of Sri Lanka. }\end{array}$ & Regression & .913 & Rejected \\
\hline $\mathbf{H}_{2 \mathrm{~d}}$ & $\begin{array}{l}\text { Capital expense has significant impact on gross domestic } \\
\text { production of Sri Lanka. }\end{array}$ & Regression & .024 & Accepted \\
\hline $\mathbf{H}_{3}$ & $\begin{array}{l}\text { Direct tax, indirect tax revenue, recurrent and capital expense are } \\
\text { significantly impact on budget deficit of Sri Lanka. }\end{array}$ & Regression & .000 & Accepted \\
\hline $\mathbf{H}_{3 \mathbf{a}}$ & $\begin{array}{l}\text { Direct tax revenue is significantly impact on budget deficit of Sri } \\
\text { Lanka. }\end{array}$ & Regression & .051 & Rejected \\
\hline $\mathbf{H}_{3 b}$ & $\begin{array}{l}\text { Indirect tax revenue is significantly impact on budget deficit of Sri } \\
\text { Lanka. }\end{array}$ & Regression & .000 & Accepted \\
\hline $\mathbf{H}_{3 \mathrm{c}}$ & $\begin{array}{l}\text { Recurrent expense has significant impact on budget deficit of Sri } \\
\text { Lanka. }\end{array}$ & Regression & .000 & Accepted \\
\hline $\mathbf{H}_{3 \mathrm{~d}}$ & $\begin{array}{l}\text { Capital expense has significant impact on budget deficit of Sri } \\
\text { Lanka. }\end{array}$ & Regression & .013 & Accepted \\
\hline
\end{tabular}

\section{Conclusion and Recommendations}

Direct tax, indirect tax revenue, recurrent expense, capital expense, gross domestic production and budget deficit are key economic variables of every country. Sri Lank has major economic problem which is continuous budget deficit. Here it can be pointed that budget deficit is increasing every year in Sri Lanka. Sri Lanka is trying to reduce or maintain the budget deficit even though Sri Lanka did not achieve from 1990 to 2015. Sri Lanka is one of the developing and low middle income country so budget deficit cannot be avoided but the problem is, budget deficit is going very highly in every year. It will be barrier for the economic development and sustainable development of the country. Sri Lanka has to work and develop the fiscal policy and economic policy to have successful sustainable development in coming recent years. Sri Lanka has major problem past more than 30 years civil war. After the civil war 2009, Sri Lanka has possible opportunity to increase investment, try to get the foreign direct investment and increase gross domestic production however Sri Lanka cannot be avoided the resettlement cost for past civil war. Huge amount of money is spending for the resettlement of civil war.

According to depth statistical analysis of this study it can be concluded that budget deficit of the country is increasing very highly in every year. Also recurrent expense of the country is increasing very highly. There is not enough contribution by the direct tax revenue to the total revenue of the country. Also there is no high level increment of capital expenses of the country. According to this study it can be stated that Sri Lankan budget deficit and gross domestic production can be changed through the greatest tax policy and economic policy on direct tax, indirect tax, recurrent expense and capital expense of Sri Lanka, there is significant positive relationship among direct tax revenue, indirect tax revenue, capital expense, recurrent expense, gross domestic production and budget deficit of Sri Lanka. Further according to the regression analysis of the study it can be found that capital expense has significant impact on the gross domestic production of the country and recurrent expense, indirect tax revenue have significant impact on the budget deficit of the country. Finally it can be concluded that Sri Lanka can maintain or reduce the budget deficit through having greatest applicable economic and tax policy on capital expense, indirect tax, 
direct tax and recurrent expense of the country. According to this study the following recommendations can be given to the government of Sri Lanka and economic policy makers of this country.

- Two major variables are involving with budget deficit of the country such as total revenue and total expense of the country. Tax revenue is major part of the Sri Lankan total revenue and also recurrent expenses are major part of the Sri Lankan total expense. Both variables should be well managed to reduce the budget deficit or maintain the level of budget deficit of the country.

- According to the analysis of the country direct tax contribution to the total revenue is very low level and indirect tax revenue has significant impact of the budget deficit. Sri Lanka should develop the successful and adequate tax policy on direct tax to increase the direct tax revenue of the country.

- Indirect tax revenue policy should be changed according to the current market situation of Sri Lanka to increase the direct tax revenue of the country. Recurrent expense of the country is increasing very high level so the government should try to control the recurrent expense.

- Gross domestic production is much important here capital expense of the country has significant impact on the gross domestic production of the country. Sri Lankan government should try to focus to increase capital expense. Government can think to the following three areas to increase the gross domestic production of the country such as tourism, agriculture \& fishing and education system.

- Sri Lanka has most traditional and beautiful tourist places in this country. Foreign people are having interest to visit to the Sri Lanka and Sri Lankan political situation also very positive for the tourism after the civil war. Sri Lankan currency value is most favor for the foreign people to spending in Sri Lanka.

- The government should try to develop more and more infrastructure facilities and high technological advancement to increase the tourism specially road, hotels, accommodation, entertainment centers, online payment system, travelling facilities, online adequate and accurate information regarding the tourism, tourism guiding centers. Sri Lanka is one of the traditional agriculture countries.

- Sri Lanka had a strong agriculture history Especially Sri Lanka was the number one tea export country in 1993. Sri Lanka is one of the Islands and it has adequate sea food facilities. Sri Lanka has huge demand for the organic fruits, vegetables, rubber, tea, coconut, and sea food in all over the world especially from European, American and developed countries.

Here one important notable thing is Sri Lanka has demand with high and fair price due to the high quality product.

\section{References}

Agbeyegbe, Terence, Stotsky J. G., \& WoldeMariam A. (2004). Trade liberalization,exchange rate changes and tax revenue in sub-Saharan Africa. IMF Working Paper WP/04/178 Washington D.C.: International Monetary Fund.

Ahmad Zubaidi Baharumshah, Evan Lau. (2007). Dynamics of fiscal and current account deficits in Thailand: an empirical investigation. Journal of Economic Studies, 34(6), 454-475. https://doi.org/10.1108/01443580710830943

Caplin, M.M. (1962). New directions in tax administration. Accounting Review, 37(2), 223-30.

Central Bank of Sri Lanka. (2015). Economic and Social Statistics of Sri Lanka. Sri Lanka: Published by Statistics Department Central Bank of Sri Lanka.

Central Bank of Sri Lanka. (2016). Annual Report. Sri Lanka: Central Bank of Sri Lanka.

Chaudhry, S. I. and Munir, F. (2010). Determinants of Low Tax Revenue in Pakistan. Pakistan. Journal of Social Sciences, 30(2), 439-452.

Cohen, S.S. (1966). To tax and to please - the greatness of the United States, National Industrial Conference, Board of New York, 15 December, 268-272.

Department of Inland Revenue. (2012). Performance Report. Sri Lanka: Department of Inland Revenue.

Dessai, M.A., Foley, C.F., \& Hines, J.R. (2004). Foreign Direct Investment in a World of Multiple Tax. Journal of Public Economics, 88, 2727-2744. https://doi.org/10.1016/j.jpubeco.2003.08.004

Eric, E., \& Jonathan, S. (1996). Taxation and Economic Growth. National Tax Journal, 49(4), 617- 642. 
Frank H. Stephen, Jürgen G. Backhaus. (2003). Corporate governance and mass privatisation: A theoretical investigation of transformations in legal and economic relationships. Journal of EconomicStudies, 30(3/4), 389-468. https://doi.org/10.1108/01443580310483600

Gacanja, E. W. (2012). Tax revenue and economic growth: an empirical case study of Kenya. Unpublished MBA Project, University of Nairobi.

Glomm G., \& Ravikumar B. ( 1998). Taxes government spending on education and growth. Review of Economic Dynamics, 1, 306-325. https://doi.org/10.1006/redy.1997.0001

Gober J.R., \& Burns J.O. (1997). The Relationship between Tax Structures and Economic Indicators. Journal of International Accounting, Auditing \& Taxation, 6, 1-24. https://doi.org/10.1016/S1061-9518(97)90010-0

Hasseldine, J., \& Hite, P. (2003). Framing, gender and tax compliance. Journal of Economic Psychology, 24(4), 517-533. https://doi.org/10.1016/S0167-4870(02)00209-X

Horn C.L, \& Tao Z. (2010). The distributional impact of income tax in Canada and China: 1997-2005. Journal of Chinese Economic and Foreign Trade Studies, 3(2), 132-145.

Howard K. (2012). Social enterprise as a means to reduce public sector deficits. Journal of Entrepreneurship and Public Policy, 1(2), 147-158. https://doi.org/10.1108/20452101211261426

Iraj A., \& Rowena J. (2001). Tobacco taxes and government revenue in South Africa. Journal of Economic Studies, $28(6), 397-407$.

James M., W., \& Sarah S. (2016). Tax policy and farm capital investment: Section 179 expensing and bonus depreciation. Agricultural Finance Review, 76(2), 246-269.

Kimura, Y. (2006). Japan's tax administration reform and the self-assessment system. Tax administration Asian Development Bank Institute course III, Siem Reap, Cambodia, 21-23.

Kirchler, E., Hoelzl, E., \& Wahl, I. (2008). Enforced versus voluntary compliance: The "slippery slope" framework. Journal of Economic Psychology, 29, 210-55. https://doi.org/10.1016/j.joep.2007.05.004

Kirchler, E., Maciejovsky, B., \& Schneider, F. (2003). Everyday representation of tax avoidance, tax evasion, and tax flight: do legal differences matter? Journal of Economic Psychology, 24, 535-53. https://doi.org/10.1016/S0167-4870(02)00164-2 